\title{
An infant with 49XXXXY syndrome: a case report
}

\author{
N.P. G. C. R. Naotunna ${ }^{1 *} \mathbb{D}$, C. Liyanage ${ }^{2}$ and N. Atapattu
}

\begin{abstract}
Background: 49XXXXY syndrome is the rarest X chromosome aneuploidy, with approximate incidence of 1:85,000100,000 male births. Worldwide, around 100 cases have been reported. In this report, we describe one such case seen in Sri Lanka.

Case presentation: A 10-day-old Sri Lankan neonate born in a tertiary care center was referred to the pediatric endocrinology unit of Lady Ridgeway Hospital due to detection of ambiguous genitalia at birth. He was the first child born to nonconsanguineous healthy parents following an uncomplicated antenatal period. He was born at term via normal vaginal delivery, with a birth weight of $2.385 \mathrm{~kg}$. The baby was active, and there was no documented hypoglycemia or alteration in basic biochemical investigations. On examination, the child had hypertelorism, upslanting palpebral fissures, flat occiput, and mild webbing of the neck. System examination was normal. Genitalia examination revealed bifid scrotum, perineal urethra, $2 \mathrm{~cm}$ phallus, and bilateral testis in situ. Hormonal analysis, including dehydroepiandrosterone sulfate, testosterone, and 17-OH progesterone levels, was normal except for an elevated level of follicle-stimulating hormone, indicating gonadal dysgenesis. Ultrasound of the abdomen detected testis located at bilateral inguinal canal, and no Müllerian structures were visible. Echocardiography showed a small patent foramen ovale with otherwise normal heart. Chromosome analysis revealed 49XXXXY syndrome.
\end{abstract}

Conclusion: 49XXXXY syndrome should be entertained as a rare possibility for ambiguous genitalia, and karyotyping is an essential investigation for evaluation of such patients.

Keywords: 49XXXXY, Ambiguous genitalia, Dysmorphism

\section{Background}

49XXXXY syndrome is a rare chromosomal aneuploidy, with a few hundred case reports published all over the world [2]. The classic triad of symptoms includes mental retardation, hypogonadism, and radioulnar synostosis with several other congenital malformations, associated medical conditions, and psychological impacts. Though many associations have been described as single case reports, to date genital malformations and ambiguity are not well described in literature. This case report

*Correspondence: chamidr101@gmail.com

${ }^{1}$ Endocrinology and Diabetic Unit, Lady Ridgeway Hospital, Colombo, Sri Lanka

Full list of author information is available at the end of the article aims to spotlight the association of genital ambiguity and 49XXXXY syndrome.

\section{Case presentation}

A 10-day-old Sri Lankan Tamil neonate born in a tertiary care center was referred to Lady Ridgeway Hospital for further evaluation of ambiguous genitalia at birth. He was the first child born to nonconsanguineous healthy young parents following uncomplicated antenatal and perinatal periods at term via normal vaginal delivery, with a birth weight of $2.385 \mathrm{~kg}$.

Neonatal examination revealed bifid scrotum, perineal urethra, $2 \mathrm{~cm}$ phallus, and palpable bilateral small testis. In addition, he had some dysmorphic features such as hypertelorism, upslanting palpebral fissures, flat occiput, original author(s) and the source, provide a link to the Creative Commons licence, and indicate if changes were made. The images or other third party material in this article are included in the article's Creative Commons licence, unless indicated otherwise in a credit line to the material. If material is not included in the article's Creative Commons licence and your intended use is not permitted by statutory regulation or exceeds the permitted use, you will need to obtain permission directly from the copyright holder. To view a copy of this licence, visit http://creativecommons.org/licenses/by/4.0/. The Creative Commons Public Domain Dedication waiver (http://creativeco mmons.org/publicdomain/zero/1.0/) applies to the data made available in this article, unless otherwise stated in a credit line to the data. 
and mild webbing of the neck. His length and occipital frontal circumference (OFC) at birth were 47 and $32 \mathrm{~cm}$, respectively. During the hospital stay, the baby was well fed and his serum electrolyte levels and serum calcium levels remained normal throughout. Moreover, there were no documented hypoglycemic events or neonatal jaundice.

Subsequent investigations on day 14 of life showed normal levels of dehydroepiandrosterone (DHEA), testosterone, and 17-OH progesterone (17-OHP), with elevated serum follicle-stimulating hormone level suggesting gonadal failure (Table 1). Ultrasound of abdomen and scrotum revealed normal adrenal glands with no evidence of persistent Müllerian structures. There was no radiological evidence of radio ulnar synostosis. Karyotyping demonstrated chromosomal aneuploidy of 49XXXXY syndrome. Parents were advised to register the sex of the child as male and advised regarding follow-up and the need for hormone replacement therapy during puberty.

The child was followed up at the endocrinology clinic at 3 months to assess growth and development. Surgical referral was done at 6 months of age for correction of perineal hypospadias, and surgery is planned for 1 year and 3 months of age.

At age 1 year, the child's growth parameters included weight below the 3rd centile $(6.8 \mathrm{~kg})$ and length between the 3rd and 15th centile $(72 \mathrm{~cm})$ according to WHO growth charts. His development at the age of 1 year was delayed, and he was commenced on physiotherapy, occupation therapy, and speech therapy at the local hospital. Follow-up ultrasound (USS) of abdomen and pelvis at 1 year was normal except for nonobstructive right-side renal calculus of $3.5 \mathrm{~mm}$.

\section{Discussion}

In 1960, Fraccaro et al. reported the first case of 49XXXXY syndrome [1]. This is the rarest X chromosome aneuploidy, with approximate incidence of 1:85,000-100,000 male births [2]. Nondisjunction of X

Table 1 Investigation summary

\begin{tabular}{lll}
\hline Investigation & Value & Reference range \\
\hline Serum sodium & $143 \mathrm{mmol} / \mathrm{L}$ & $135-150 \mathrm{mmol} / \mathrm{L}$ \\
Serum potassium & $4.7 \mathrm{mmol} / \mathrm{L}$ & $3.5-5.3 \mathrm{mmol} / \mathrm{L}$ \\
$\mathrm{FSH}$ & $22.59 \mathrm{IU} / \mathrm{L}$ & $0.09-2.41 \mathrm{IU} / \mathrm{L}$ \\
$\mathrm{LH}$ & $12.69 \mathrm{IU} / \mathrm{L}$ & $0.19-3.81 \mathrm{IU} / \mathrm{L}$ \\
$\mathrm{DHEAS}$ & $1.269 \mathrm{nmol} / \mathrm{L}$ & $0.9-5.8 \mathrm{nmol} / \mathrm{l}$ \\
Testosterone & $6.3 \mathrm{nmol} / \mathrm{L}$ & $2.6-13.9 \mathrm{nmol} / \mathrm{l}$ \\
$17-\mathrm{OHP}, 0$ minute & $8.6 \mathrm{nmol} / \mathrm{L}$ & \\
$17-\mathrm{OHP}, 30$ minute & $18.9 \mathrm{nmol} / \mathrm{L}$ & $<30 \mathrm{nmol} / \mathrm{L}$ \\
\hline
\end{tabular}

FSH follicle-stimulating hormone; $L H$ luteinizing hormone; DHEAS dehydroepiandrosterone sulfate; 17-OHP 17-hydroxyprogesterone chromosomes during both meiosis I and II is the probable chromosomal anomaly leading to $49 \mathrm{XXXXY}$ syndrome $[3,4]$.

Initially this was considered as a variant of Klinefelter syndrome, but the prevalence of moderate to severe mental retardation with low intelligence quotient (IQ) and multiple associated malformations in 49XXXXY syndrome demarcates the differences between these two clinical entities [2].

The classic triad of symptoms includes mental retardation, hypogonadism, and radioulnar synostosis, though our patient did not have the latter finding [2]. Other clinical manifestations include microcephaly with short stature; distinct facial features such as round face, ocular hypertelorism, upslanting palpebral fissures, flat nasal bridge, and cleft palate; musculoskeletal defects such as genu valgum, pes cavus or planus, clinodactyly, scoliosis, hip dysplasia and hypotonia; congenital heart defects, with patent ductus arteriosus being the most common [5]; and delayed neurocognitive development with low IQ levels. Moreover, it can be associated with immunodeficiency, making patients susceptible to infections.

A few case reports have highlighted the association of genital ambiguity with this syndrome $[7,8]$. One such case describes a 2-month-old baby with micropenis and right undescended testes. Another newborn had a normal stretched penile length with penoscrotal hypospadias and bifid scrotum, with $1 \mathrm{ml}$ testes in situ bilaterally. A 26-month-old baby had bilateral undescended testes with the penis buried with a urethral shelf at the urethral opening and penoscrotal webbing. In contrast to these, our patient had a unique presentation with micropenis, perineal hypospadias, and bifid scrotum with small palpable testes.

There has been a reported case of diabetes mellitus in an 18-year-old 49XXXXY patient, though this is common among children with Klinefelter syndrome [9].

Behavioral and development aspects in view of 49XXXXY have been studied widely, and many elderly patients with this syndrome had emotional lability, low frustration levels and shyness, occasional irritability, temper tantrums, and resistance to routine change $[2,6]$. Marked delay was noted in language and speech development, with a clear discrepancy between language expression and comprehension. This child already had speech delay, and he needed further followup for assessment.

Hypergonadotropic hypogonadism needs to be evaluate at the age of puberty, and hormone replacement therapy with intramuscular (IM) testosterone should be initiated under endocrinology follow-up. 


\section{Conclusion}

Knowing the association of 49XXXXY syndrome in this child with ambiguous genitalia is beneficial as a multidisciplinary approach can be adopted for further management to ensure quality of life. Also, it is important to consider this rare possibility in a child with ambiguous genitalia and to stress the importance of karyotyping for evaluation.

\section{Acknowledgements}

To the parent of the child.

\section{Authors' contributions}

$\mathrm{CN}$ collected the information and wrote the manuscript. NA evaluated and managed the patient and helped in manuscript writing. CL did the initial assessment of the patient.

\section{Funding}

None.

Availability of data and materials

Not applicable.

\section{Declarations}

Ethics approval and consent to participate

Not applicable.

\section{Consent for publication}

Written informed consent was obtained from the patient's legal guardian for publication of this case report and any accompanying images. A copy of the written consent is available for review by the Editor-in-Chief of this journal.

\section{Competing interests}

The authors declare that they have no competing interests.

\section{Author details}

${ }^{1}$ Endocrinology and Diabetic Unit, Lady Ridgeway Hospital, Colombo, Sri

Lanka. ${ }^{2}$ Paediatric Unit, Provincial General Hospital, Badulla, Sri Lanka.

Received: 24 August 2021 Accepted: 11 November 2021

Published online: 30 December 2021

\section{References}

1. Fraccaro M, Kaijser K, Lindsten GJA. Child with 49 chromosomes. Lancet 1960;2:899-902

2. Tartaglia N, Ayari N, Howell S, et al. 48, XXYY, 48, XXXY and 49, XXXXY syndromes: not just variants of Klinefelter syndrome. Acta Paediatr. 2011:100(6):851-60.

3. Leal CA, Belmont JW, Nachtman R, Cantu JM, Medina C. Parental origin of the extra chromosomes in polysomy X. Hum Genet. 1994:94:423-6.

4. Hassold T, Pettay D, May K, Robinson A. Analysis of non-disjunction in sex chromosome tetrasomy and penta-somy. Hum Genet. 1990;85:648-50.

5. Karsh R, Knapp R, Nora J, et al. Congenital heart disease in 49 XXXXY Syndrome. Pediatrics. 1975;56:462-4.

6. Lomelino CA, Reiss AL. 49, XXXXY syndrome: behavioral and developmental profiles. J Med Genet. 1991;28:609-12.

7. Hammami MB, Elkhapery A. Sexual and developmental aspects of 49 XXXXY Syndrome: a case report. Andrologia. 2020;52(10):e13771.

8. Etemadi K, Basir B, Ghahremani S. Case report: neonatal diagnosis of 49, xxxxy syndrome International. Int J Reprod Biomed. 2015;13(3):181-3.

9. Kim HJ, Kim D, Shin JM, et al. 49, XXXXY syndrome with Diabetes Mellitus. Horm Res. 2006;65:14-7.

\section{Publisher's Note}

Springer Nature remains neutral with regard to jurisdictional claims in published maps and institutional affiliations.
Ready to submit your research? Choose BMC and benefit from:

- fast, convenient online submission

- thorough peer review by experienced researchers in your field

- rapid publication on acceptance

- support for research data, including large and complex data types

- gold Open Access which fosters wider collaboration and increased citations

- maximum visibility for your research: over 100M website views per year

At BMC, research is always in progress.

Learn more biomedcentral.com/submissions 